This is the version of the chapter accepted for publication in Tezcür, Günes Murat, (ed.), Kurds and Yezidis in the Middle East: Shifting Identities, Borders and the Experience of Minority Communities. London: I.B. Tauris - Bloomsbury, pp. 115-132. (Kurdish Studies Series)

https://doi.org/10.5040/9780755601226.ch-007

Accepted version downloaded from SOAS Research Online: http://eprints.soas.ac.uk/32786

Re-use is subject to the publisher's terms and conditions

\title{
Orientalist Views of Kurds and Kurdistan
}

\author{
Zeynep N. Kaya
}

\section{Introduction}

This chapter explores the Western perceptions of Kurdistan and Kurdish political agency in the late nineteenth and early twentieth centuries. These perceptions had an important impact on Kurdish political elite's pursuit of national legitimacy in this period and continue to remain to have an influence on Kurdish politics today. This chapter seeks to answer a number of questions: What were the underpinning ideas behind the orientalist and western perceptions of the Kurds in the late nineteenth and early twentieth centuries? How did these influence Kurdish political elite's engagement with international actors and the Ottoman Empire? How did this engagement shape Kurdish political movements and their pursuit of political legitimacy? In addressing these questions, the chapter connects western imperial powers' activities in the Ottoman territories with the construction of Kurdish national identity and the development of Kurdish politics since then. It shows that ethnographic maps of the region produced by Western geographers were adopted and used by Kurdish nationalists in the early twentieth century and onwards and became key sources for mapping Kurdistan.

Orientalist perceptions of non-western peoples had strong perennialist and civilisationist lenses. These perceptions were informed by the studies and observations of Western geographers, military officers, economic entrepreneurs and missionary agents during their travels and engagements in non-western territories. Eastern territories of the Ottoman Empire, especially eastern Anatolia and Mesopotamia, became a focus area for Western imperial states in the late nineteenth century. This was partly because of economic and political reasons, such as trade routes and increased Russian influence in the area, as well as the presence of Christian populations. The geographical and ethnographic studies undertaken by European travelers and how they informed imperialist powers' policies in the period leading up to, during and after World War I significantly influenced most of the territorial demarcations in the Middle East and the political fate of the Kurds. Even so, the resultant political and territorial settlement was also shaped by the strategic, economic and political interests of the imperial powers and the rivalries between them.

This chapter focuses on the orientalist conceptions of the national identity of the non-western peoples, the peoples of the Ottoman Empire in this case. Western travellers' and states' perceptions of nationality informed the construction of a retrospective view on Kurdish national identity and territoriality today. Western conception of national identity was based on views that for a community to be considered as a nation, it needs to have a certain level of development, unified political leadership and a sense of shared identity and interest. However, Kurds were seen as a tribalistic, divided and underdeveloped society. As discussed by Ekrem Karakoç and Ege Özen, such views exhibit uncanny resemblances to the Turkish views of the Kurds in the early 21 st century.

Interestingly, the European ethnographic studies and cartographic depictions of the people of the region, including the Kurds, significantly informed the territorial conceptions of Kurdish national identity and the ways through which they constructed the Kurdish homeland. Indeed, European imperialism laid the groundwork for the world today and in this historical process geography played a significant role as "none of us is outside or beyond geography". ${ }^{i}$ Cartography had huge power in the nineteenth and early twentieth centuries because it allowed for "achieving ideological supremacy over space".ii Mapping reflects the wider ideological and political discourses and is the outcome of communication between cartographers, the goals of their study, the political offices and wider society. iii Neither territory nor its cartographic depictions can be taken for granted as static and ahistorical things. Maps are components of a "visual language" that communicates strategic interests and ideologies.iv Even when the aim for the production of a map is not propaganda, maps reflect unconscious biases and assumptions situated in the particular values, ideologies, political interests of the producer and the institutions and history they are situated in. ${ }^{\mathrm{v}}$ It is neither possible to escape geography nor the political and economic values and interests that shape its depictions and imaginations. 


\section{European context that affected Western states' view of non-Western peoples}

Dominant political ideologies and the conceptions of development and political legitimacy in Europe in nineteenth century framed European actors' perceptions of the Ottoman Empire and its peoples. Therefore, it is important to provide background for this historical European context and for the key political ideas that shaped this context.

Nineteenth and early twentieth century Europe is characterised by increased centralisation of political and economic power and decision-making under militaristic nation-states. It also cultivated a form of imperialism that was driven by rivalry between these powerful states in most of the rest of the world. ${ }^{\mathrm{vi}}$ In this world, nationalism was one of the most significant political forces and ideologies vii In the late eighteenth century, the British colonies in North America rejected the monarchical authority of the British Empire and declared American independence based on the notion of national sovereignty. Similarly, in Europe, the French Revolution was based on the ideas of nationhood, republicanism and liberty. Both revolutions saw the republican nation as the only legitimate form of political order to realise this latter goal of liberty.

Nationalism provided the collective ideology and legitimacy for the state to undertake the endeavour to accomplish individual freedom through institutional arrangements. Nationalists envisioned the possibility of a community bound together through common memories, therefore they saw nationalism as a benign force. In this context, the ideal of a nation and nation-state were perceived to be imbued with certain values such as liberalism, capitalism, democratic institutions and popular sovereignty. In this model, the state could ensure a harmonious society and was seen as progressive if it embraced popular citizenship instead of imperial rule. viii Collective governance, or democracy organised on national lines, defined as "the institutional arrangement for arriving at political decisions in which individuals acquire the power to decide by means of a competitive struggle for the people's vote"ix emerged as the dominant form of governance over time.

Democracy and nationalism complement each other because nationalist groups or movements seeking selfdetermination see this goal as a democratic collective right. ${ }^{x}$ By definition, the democratic enterprise has always been based on a defined group of people. As a result, constructing and defining a distinct nation came to be seen as a prerequisite for the formation of a democratic state. In turn, determining who belongs to 'us' and who should form the nation is seen as a prerequisite for this democratic endeavour. Building a state based on a claimed distinct identity is perceived as a rational route due to the belief that it brings solutions to political problems. It also provides suitable political and social circumstances for the advancement of better governance and development. Yet, history showed that the act to determine who belongs to the nation has also resulted dictatorial or violent forms of nationalism utilizing suppressive and non-democratic methods. . $^{\mathrm{i}}$

A key outcome of this form of thinking in the nineteenth century-Europe was the emergence of selfdetermination, defined as the 'nationality principle' or 'self-governance' at the time. Self-determination has become one of the most crucial international norms in relation to nationalist claims to justify separation from empires in the nineteenth century, gaining independence through decolonisation in the nineteenth and twentieth centuries, and in shaping borders during the dismemberment of communist states at the end of the Cold War, as well as secessionist, irredentist or autonomist demands in other contexts. xii Selfdetermination as a concept is widely discussed in the literature, and one thing that is agreed upon is the difficulty in defining this concept whether it is defined as a legal or political term. As a principle of international law, it is generally understood in a way that prioritises the stability of the international system and protects the sovereignty of states. Alternatively, it is interpreted as a political goal to achieve the rights of people to determine their political future, as a people of a state or in the form of autonomy or secession. Nationalist groups and their supporters (lobby groups, diasporas, states or international organisations) are proponents of this meaning of self-determination. Lastly, self-determination as an idea, as an analytical concept, is utilised in the scholarly work on nations and nationalism to understand state formation, nation building, ethnic conflict, nationalist political movements and other related issues. 
In the nineteenth century, a civilizational interpretation of the 'nationality principle' was dominant. This view was dominated by the western orientalist thinking of the time, and argued that not all peoples are ready for self-governance. Only when they reach a required level of civilizational development should the nationality principle apply to a people. xiii By the end of the nineteenth century, the idea of a national identity had become a common sensical idea and nationality principle, , became a principle used in liberation movements against the imperial powers, notably the Habsburgs and the Ottomans, and establishing a new state. It was believed that when an independence movement achieves separation, it would be deemed a nation and would be able to establish its popular sovereignty over a defined territory and thus realise the ideal of popular national sovereignty. xiv Especially after World War I, nationalist ideology and selfdetermination became directly linked to popular sovereignty. ${ }^{\mathrm{xv}}$

Key characteristics of the logic of the state in nineteenth century Europe were industrial capitalism/development and centralisation, which coincided with the emerging nationalism in place of feudal and monarchical affiliations. This led to the perception that industrial development and nationalism go hand in hand, and a centralised economy, education system, military, police and bureaucracy were seen as the outcomes or products of the consolidation of national integration. The reverse is also possible; nationalism could be considered as the outcome of these centralising forces. xvi As a result of the coincidence of industrial capitalism, development and nationalism, the ideas of development and civilisation became associated with the nation, and its distinct identity, territory, culture, language and values. In this context, racial and ethnic groups that appeared to constitute the majority in a particular society were perceived to overlap with such processes. If this perceived overlap was present, a nationalist movement was seen to be a legitimate force or an entity to be taken seriously. Envisioning a national ideal and its 'essence' as a universal phenomenon (as autonomous, ahistorical and natural) has become an integral component of explaining state-building processes or attempts to form a state in the nineteenth century. The success of the German and Italian unifications and the maturing of the British and French (and American) nationalisms legitimized and popularized the idea that the nation-state is the progressive and universal political unit.

What is important is that, the conception of nationhood and statehood in the nineteenth-century Europe and its overlap with development and industrial capitalism generated the lenses through which European colonial forces imagined the political future of non-European territories. They assumed that the consolidation of nation-states around specific identities within well-defined territories under a clear national leadership was an appropriate model for these areas as well. National communities were thought as entities with common identity traits and with a historical attachment to a defined territory and shared culture. This understanding of the nation was accompanied by the belief that nationalism and the nation-state are natural and progressive.xvii If such a people exist and if they have a nationalist leadership espousing these ideas, then they were seen to deserve being categorised as a national liberation movement. The lack of apparent shared identity or a nationalist leadership among a community or people were considered as indicators of backwardness. This rendered, in the orientalist perspective, these people as unable to govern themselves. European state officials, travelers, traders, and geographers often wrongly "projected upon local parochial communities the belief that national concerns not local issues should be at the forefront of local consciousness" and where that appeared to be missing, they were considered as being unready for national attainment. xviii

\section{Western imaginations of ethnic geographies in the Ottoman Empire and the Kurds ${ }^{\mathrm{xix}}$}

European officers' and travellers' studies and observations about the peoples of the eastern territories of the Ottoman Empire, including the Kurds, had an impact on the way Western policies were developed towards the Empire and its people during and after the World War. These views were both praising and critical of the Kurdish political elite and Kurdish society based on tribal structures. This highly biased view was an important factor in forming the perception that Kurds are not ready to attain statehood. For instance, thee studies undertaken by British colonial officers and travellers visiting eastern territories of the Ottoman Empire, including writers, anthropologists, linguists and geographers, saw the areas they explored and visited from this perspective, such as Mark Sykes' 'The Kurdish Tribes of the Ottoman Empire' (1908), Francis Maunsell' "Kurdistan" (1894) and Fredrick Millingen's Wild Life among the Koords (1870). For 
instance, Millingen extensively discussed the role of tribal feuds and intertribal war, and pointed to the primitive culture of the Kurds. Both Maunsell and Sykes reported on the intertribal fighting among Kurds, especially those that formed the Hamidiye regiments, and the negative impacts of this had on security the region. ${ }^{x}$ These writers also talked about the Hamidiye cavalry's oppression of the Armenians. For instance, Maunsell wrote that Kurds were bigoted and constantly quarreled with Christians. ${ }^{\text {xi }}$

The European explorers' and travellers' explorations, activities and studies in non-European territories in the nineteenth century informed the way their states exerted power to reshape the political division of the Middle East in the early twentieth century. Orientalist constructions of geography were shaped and informed by political and cultural values in the European context, as explained in the previous section, the interests of the states and the different sources of information, including local informants and intercommunal perceptions on the ground. Such information and perceptions influenced the Western travellers' biases.

\section{The western idea of a territorially contained peoples}

This section elaborates on the imaginations of ethnic territories by Western actors in their attempts to chart and map the East and its peoples, and generate new political boundaries during and after the dissolution of the Ottoman Empire. The underpinning ideas and views behind the western geographic study and mapping of non-Western territories and peoples in this period shaped the resultant imaginations. The western perspective projected an understanding of the nation (as experienced, or thought to be experienced in Europe) on rebel groups and the groups with distinct cultures and customs. In addition to this, accompanying the orientalist and colonial views on national identity and territoriality was the idea that the ability to form national unity around a specific identity and on a demarcated territory required a certain level of civilizational attainment, as explained in the previous section.

The relationship between mapping and the construction of a nation or a people has changed over history. This relationship in each period is framed by global and regional power configurations and ideas about the world pertaining to that historical period. Processes and structures of a particular long-term historical period, and the international order it generates frame the assumptions, ideologies, perceptions and interests that underlie territorial imaginations. Moreover, political and ideological discourses at international, regional and local levels provide the supporting context for the production of geographical knowledge.xxii This means, the meaning of the territorial state (political entity) also differs in different international orders in which states can have distinct economic structures and different inter-state dynamics.

Agnew identifies three such international orders in recent world history: 1815-1875, 1875-1945 and 19451990. The first and part of the second period are particularly relevant for this chapter.xxiii In the 1815-1875 international order, according to Agnew, European states reached a period of balance of power in their relationship. The Concert of Europe that emerged after the Napoleonic wars and nationalism came to be seen as the most apt legitimizing ideology for states and as an indicator of more superior systems and values of the western world vis-à-vis others. Agnew's second international order from 1875 to 1945 was one of intensified rivalry between imperialist powers over control of and access to areas, trade routes and resources.xiv In both these periods, an orientalist view of the non-western world and ideas of civilisation and underdevelopment shaped the perspective of the European travellers and their states, and informed perceptions about the peoples of the region and its mapping and study.

Looking at what was happening in the first period (1815-1875) in the eastern territories of the Ottoman Empire, we see that western states, Italian, German and French travellers, missionaries and states were already active, including in the areas where Kurdish communities resided alongside other communities. Britain's colonial power was on the rise and, as the century progressed, the British became increasingly more involved in the Middle East. European travellers were particularly interested in the fate of Christian populations. In the second period, especially until the end of World War I, European explorations were made mainly for strategic purposes to promote and protect state interest against other European states' interests in the region. In this era, European powers were heavily involved in the demarcation of the 
territories of the new states and in identifying the specific colonial power's position and role in the governance of the new territory. $x x v$

The sociological thinking in the nineteenth century in Europe, as explained in the previous section, further reinforced the idea of a political territorial state. xxvi Social science and geographers in the nineteenth and early twentieth century contributed to the study of "state-centred political geographies, which reinforced the idea that the modern nation-state is natural and progressive.xxvii Nationalism or national identity, in this period, was believed to have an essence, an origin, which the nationalist intelligentsia tried to revive - an idea contemporary perennialist and ethno-symbolist approaches in the nationalism studies have explained.xxviii In nineteenth century Europe, three geographical assumptions were crystallised: (1) state territories became fixed units of sovereign space; 2) binary divisions set in such as national/international or domestic/foreign; 3) and the state came to be seen as a prior to and a container of society.xxix Enabled by these assumptions, a link between spatially demarcated territories and state sovereignty led to the 'territorial trap', and the fragmentation of the world into territorial states served as a justification for this trap. ${ }^{\mathrm{xxx}}$ The idea of the territorial state as the container of society became 'common sensical' and was reproduced. Popular sovereignty over an inhabited territory created a people-territory relationship in which territory began to define the people.xxi

This ideal state unit was filled with values that represented progress, liberalism, development and civilisation. These values and ideals underpinned the colonial powers' perceptions of the other, their engagement with non-European contexts and the way they interpreted their findings and information they gathered through their explorations and studies. Peoples that do not appear to be progressive, liberal, or civilised were deemed not ready to attain the status of nationhood and establish a state of their own. These values informed Western states' and their agents' visualisation of the future of the Middle East and the Kurds in line with their strategic interests and the configurations shaped by the heightened imperial rivalry both leading up to and after the First World War.

The orientalist geographic studies and interpretations of this period were complex and multidimensional. The European philosophical thinking and perspectives on the ideal and most progressive form of governance and the political unit were integral to colonial geographical studies and map-making. Western cartography presented Europe as civilised and powerful, at the centre of the earth, while the rest of the world was presented as uncivilised and weak. For instance, in the seventeenth and eighteenth century maps, Europe was put in a central and dominant position and it was even sometimes decorated into the physical shape of a queen stretching Europe's tentacles around the globe with the world submitting to it.xxii The European self-image presented in these maps, imbued with symbols, writings and drawings of peoples, depicted Europe as "powerful, civilised, clothed, and cultured; the rest of the world [as] subdued, exotic, savage, half-naked and primitive". xxxiii This kind of iconography became less prominent in nineteenth century maps. This was due to the switch to more 'scientific' looking maps and advancement in mapping techniques (Black 2000). Despite the changes in mapping techniques, the orientalist view exemplified by such iconographies that informed earlier maps continued to exist in the studies of colonialist officers and travellers.

In the colonial era, European powers and their agents, were heavily interested in objectifying, classifying and charting/mapping.xxxiv Colonial explorers, officers, engineers, geographers, and anthropologists were driven to create rational and universal knowledge about the world. Therefore, map-making and geographic work even for purely exploratory and economic reasons tried to identify unifying or dominant identity markers such as language, customs, religion in their study of the peoples in the Middle East in Ottoman and Iranian imperial territories. They usually depicted the non-Western as underdeveloped, uncivilised, tribal and primitive, therefore, undeserving of national self-determination, which in their thinking justified colonisation. When it comes to the Middle East, such perspectives were especially targeted at non-Christian communities. For instance, the Christian communities in these territories, such as Armenians, Assyrians, Nestorians, were depicted as less backward and with less degrading language. With regards to the Kurds, some travellers described Kurds more favourably compared to Arabs and Turkmans and blamed the underdeveloped and uncivilised life among the Kurds on their Ottoman and Persian rulers. ${ }^{\text {xxx }}$ Others described Kurds as uncivilised and argued the Ottoman and Persian rulers have not managed to change 
them. They were also portrayed to be inferior to Christians in terms of intellect and to have savage characteristics. xxxvi

\section{Kurds and Kurdistan in the eyes of Western travellers}

European travellers and writers visited the Kurdish populated region as state agents, army officers, scientists, researchers or journalists in the eighteenth, nineteenth and early twentieth century, and they created numerous definitions and cartographic depictions of Kurdistan. They were interested in Kurdistan for several reasons and these reasons influenced their findings and the way they conducted research. Initially the western interest in the region was for economic and religious purposes. Kurdistan is located on important communication and trade routes, therefore they produced a number of writings, reports and maps for economic purposes, which included references to and observations about the Kurds and Kurdistan.

Italian merchants were among the earliest travellers to Kurdistan and they were interested in the trade routes going through the area and the region's economic potential. They wrote the oldest European accounts, including the first Kurdish grammar book and dictionary in 1789, and produced several other writings on the political structures and geographical location and features.xxxvii German travellers also had been writing about Kurdistan since the eighteenth century based on their study of the region and its features, particularly the transport routes. German engagement was further facilitated by its close relationship with the Ottoman Empire from the mid-nineteenth century onward.xxxviii Germans invested a big share of funding for the Baghdad Railway Project, whose construction started in 1903, envisioned to go through Kurdistan. The British were also interested in trade and economic benefits initially; for instance, the East India Company was very active in the region. Similarly, the French were engaged in economic activities and had extensive economic links with the Ottoman Empire. The French had built railway lines in Ottoman territory xxxix and had a 40 percent share in the Baghdad Railway Project. Russians produced the earliest accounts of the trade routes in the region. ${ }^{\mathrm{xl}}$

Western states, particularly Italy, France and the United States, and later the British, were also heavily engaged in missionary activities in the eastern territories of the Ottoman Empire. They were particularly focused on the Christian communities. American missionaries, active in Kurdistan since the early nineteenth century, published several studies and reports on the Kurds. Italian and French Catholic missionaries carried out activities in the region, especially in the Mosul Province of the Ottoman Empire, and members of these missions wrote about different aspects of the Kurdish way of life, religion and geography. xli The missionaries' close focus on local Christians influenced their and other Westerner perspectives of Kurds and Muslims. It also played a role in the deterioration of inter-communal relations in the region. Westerners distinguished between local Christians and Muslims and perceived the former being more "civilized", while still maintaining a more pejorative view of all the locals in these territories, including Christians. The Russian and the French devoted particular attention to the Armenians in the late nineteenth and early twentieth century, which added to the tension in communal relations between Kurds and Armenians. xlii In turn, as discussed by Ohannes K1liçdağ in his chapter in this volume, Armenian intellectuals perceived Kurds as "uncivilized" but argued that it was in the best interest of the Armenian community to help Kurds achieve a higher level of development.

The maps and reports the Europeans produced mainly relied on their studies and observations, but it is likely that they came across earlier descriptions of Kurdistan by Muslim historians and travellers such as Şerefhan, Evliya Çelebi and Koyi. For instance, Rawlinson, a traveller and military officer, who visited the areas northern Mesopotamia and the Zagros mountains, read the Sharafname (1596) written by the ruler of the Ottoman Emirate of Bitlis. xliii Yet there was limited writing and cartographic work on Kurdistan produced by local researchers in the nineteenth and early twentieth century. Therefore, it is safe to say that Europeans' cartographic study of the area and its people mainly relied on their orientalist point of view and colonial epistemologies and methodologies of geography. Such a perspective projected and interpreted information gathered through a colonial perspective, essentialising what is studied. For instance, European travellers and writers adopted the myth that Kurds were the descendants of the Medes despite lack of historical evidence indicating to that. xliv 
In the second half of the nineteenth century and early twentieth century, the European states became even more interested in these areas due to intensified imperial rivalry. Therefore, their strategic interests played a significant role in their interpretations of the local context. Each imperial state wanted to gain political and economic supremacy in the region. Particularly the Baghdad Railway project increased the importance of the area and escalated imperial rivalry as each power wanted to enjoy the highest benefit from this new transport and communication route. ${ }^{\mathrm{xlv}}$ Russians further expanded their interests in Caucasia and its south due to increasing involvement by other European powers in the area. These Western powers as well as Ottoman and Iranian powers considered this a threat. xlvi The imperial rivalries in the region shaped the future of most of the region, which in the long-term led to the frustration of the Kurdish nationalist desire to statehood after World War I.

European travellers produced several maps of the region, including maps depicting Kurdistan. One of the first maps produced by a Western traveller was that by English traveller Claudius Rich who visited the Middle Eastern territories of Ottoman and Iranian Empires in the first two decades of the nineteenth century. xlvii The Germans in 1854 later produced an ethnographic map of Armenia, Azerbaijan and Kurdistan, which illustrated trade routes. xlviii Karstov, a Russian military officer, produced a map of Kurdish tribes in 1896 (O'Shea 2004: 112). The first map that specifically focused on Kurdistan was produced by Maunsell, a British military officer, after his travels in the region in 1892. The map provided detailed information on the geography of Kurdistan, Kurdish habitation and habitation by other communities. xlix The British Government used Maunsell's projections of the ethnographic composition of the area when strategic plans about the region were being made in the period before World War I. The British Foreign Office's ethnographic map of the area, produced in 1919 (but relying on data from prior to the First World War) reflected the Foreign Office's position on the territorial extent of Armenian habitation. O'Shea states that this was because at the end of the War, the Allied forces wanted to weaken Ottoman territorial claims in eastern Anatolia and therefore produced a map that indicated large Christian habitation in the region. ${ }^{1}$

The colonial and imperial powers also took a direct role to influence boundary drawing in the eastern territories of the Ottoman Empire as early as mid-nineteenth century. The boundary between the Ottomans and Persians was set in 1639 with the Zohab Treaty and demarcated a wide border area (about 100 kilometres), in which several Kurdish tribes were located. The demarcation of this border between Turkey and Iran involved significant European presence was not finalised until the 1910s.i This location provided the Kurds some degree of autonomy and they were able to change alliances between the two empires as it fit them. This location made the Kurds and other communities living in this zone vulnerable because they were easily manipulated by external imperial powers and their specific interests. The maps produced in this period played an important role in the drawing of boundaries before and after the First World War, including Maunsell's maps. lii

The studies and explorations undertaken in Kurdistan and the reports and outputs produced by European travellers and their governments' officials in the nineteenth and early twentieth centuries were used to formulate European states' policy with regards to the Kurds before, during and after the First World War. Ironically, the cartographic information on the Kurds and anthropological studies on their distinct features also constituted the foundation of Kurdish nationalist cartography and historiography later in the twentieth century. Kurdish nationalists replicated these maps or improvised on them to imagine the Kurdish homeland and its extent. Maunsell's and other travellers' maps became widely accepted and used by Kurdish nationalists, who improvised on them and produced their own maps in the early twentieth century and later. ${ }^{\text {liii }}$

For instance, Sherif Pasha's map included in the Memorandum demanding Kurdish self-determination in 1919 at the Paris Peace Conference was constructed based on the maps produced by Western travellers, British and German armies and entrepreneurs in the region. . $^{\text {iv }}$ The Conference hosted many delegations representing different peoples and groups, however not all these delegations were given official hearings, including the Kurdish delegation. Sherif Pasha, ${ }^{\text {lv }}$ an Ottoman diplomat in Paris, acted as the Kurdish representative to the British Ambassador in Paris and as the head of the Kurdish Delegation to the Conference. The Pasha prepared a Memorandum on the Claims of the Kurd People (Kurdish Memorandum) that included a map of Kurdistan that he produced. At the Conference, maps were widely 
used by multiple different delegations as tools to persuade others of the existence of territorially identifiable peoples that should be considered as nations around the world ${ }^{1 v i}$ and the Kurdish representation was no exception to this. Sherif Pasha's Memorandum demanded a free Kurdish state and its main goal was to show the soundness of Kurdish demands against Armenian claims. It argued that the districts claimed by the Armenians were actually within the boundaries of Turkish Kurdistan and stated that if contested districts were to be included in the new Armenia, disorder and irregular warfare would be inevitable. Ivii It defined the ethnographic frontiers of Turkish Kurdistan as follows:

in the North at Ziven, on the Caucasian frontier, and continue westwards to Erzéroum, Erzindjan, Kémah, Arabkir, Benismi, and Divick; in the South they follow the line from Haran, the Sindjihar Hills, Tel Asfar, Erbil. Kerkuk, Suléimanié, Akk-el-man, Sinna; in the East, Ravandiz, Bash-Kalé, Vizir-Kalé, that is to say the frontier of Persia as far as Mount Ararat..$^{\text {lviii }}$

However, Sherif Pasha was not considered representative of the Kurds by the European powers and, despite Pasha's efforts, eventually it was not taken seriously by the British. . $^{\text {ix }}$ The Pasha was neither chosen nor supported by powerful local Kurdish leaders either and came to be seen as disconnected from the Kurdish masses and Kurdish leaders in Istanbul. The Conference received a series of telegrams from Kurdish chieftains stating that they did not recognise Sherif Pasha as a legitimate representative and protested against his map of Kurdistan. Emin Ali Bedirhan, one of the leaders of the Society for the Advancement of the Kurds in Istanbul, vehemently opposed to Pasha's plans, especially the extent of Kurdistan on his map. ${ }^{1 x}$ Sherif Pasha's map left the Lake Van area, which was considered as the heart of the Armenian homeland, out of his map of Kurdistan. It is said that the Pasha also made a secret arrangement with the Armenian Delegation for the formation of both Armenia and Kurdistan. ${ }^{\text {xi }}$ Some other Kurdish chieftains also sent telegraphs to the conference to condemn Sherif Pasha's initiative for a Kurdish state and to assert that they did not want separation from the Turks, emphasising their fraternity instead. Ixii The Pasha resigned from his position as Kurdish representative April 1920 and from this point on, the British interacted directly with local leaders. .xiii $^{-}$

\section{Post-World War I settlement and the Kurds}

In the early twentieth century and after, western states continued to engage with the Kurds, to carry out their missions and interests in the region. However, they did not give full support to the idea of Kurdish state. European colonial officers and travellers projection of a European understanding of the nation and their perspectives on the peoples of the Ottoman Empire through these lenses contributed to the view that the Kurds did not have the characteristics of a nation and were not seen as a legitimate group to deserve national liberation because of the Kurdish society's 'under-developed', tribal and divided nature. The discussions about the Kurds during World War I period are clear indicators of such perceptions.

Especially the British, who played a significant role in shaping the political fate of the Kurds in this period, perceived the fragmented and multiple Kurdish voices and rivalries between different leaders as a drawback and an impediment for forming a Kurdish state. ${ }^{\text {xiv }}$ Lloyd George, the British prime minister between 1916 and 1922, wrote "no Kurds seemed to represent anything more than his own particular clan". ${ }^{\mathrm{xv}}$ This was seen as a stark contrast to the coherent, stronger and unified Armenian movement supported by an influential and well-organised Armenian representation. lxvi Perceptions about the Kurdish dividedness and unreadiness to form their own state have continued to shape the political discourse about the Kurds until present. The role of the Kurds in the suppression of minorities and treatment of Armenians under Ottoman rule, especially through their involvement in the Hamidiye Cavalry under the Abdulhamid II's reign, also tainted the perceptions of Western actors towards the Kurds and weakened the case for a Kurdish states. ${ }^{\text {Ixvi }}$

During the Paris Peace Conference, it was decided that the Ottoman territories would be divided between the British, French, Italians and the Greeks. However, these external actors had different expectations and plans for the territories. Rivalries and dynamics within this cohort of countries made it hard to decide the territorial boundaries of potential political entities. Each external actor wanted new political entities to help fulfill their own economic, political and strategic plans in the region. In the end, European influence over the eastern territories of the Ottoman Empire, remained limited even if territories south of these lands, 
which included the Mosul province with its significant Kurdish population, divided and put under British and French mandates (later Iraq and Syria respectively).

The provisions of the Treaty of Sèvres pertaining to the Kurds showed that the nineteenth century views that Kurds were considered as being unready for national attainment were still shaping the thinking of the European powers after World War I. Signed in August 1920 between the Ottoman Empire and the victorious powers (but not ratified), the Treaty set the terms for the partition of the Ottoman territories and its Articles 62-64 dealt with the status of the Kurds. The Kurdish nationalist historiography usually sees the Treaty of Sèvres as a legal guarantee for the establishment of a Kurdish state and argue that if it was implemented a Kurdish state would have been established. However, a closer look at the Sèvres document shows that the guarantee appears far more elusive than assumed. The Article 64 of the Treaty makes reference to the capacity of the Kurds to become independent, implying civilizational and national attainment and readiness for forming a state:

If within one year from the coming into force of the present Treaty the Kurdish peoples within the areas defined in Article 62 shall address themselves to the Council of the League of Nations in such a manner as to show that a majority of the population of these areas desires independence from Turkey, and if the Council then considers that these peoples are capable of such independence and recommends that it should be granted to them, Turkey hereby agrees to execute such a recommendation, and to renounce all rights and title over these areas.

The British had abandoned the idea of creating a Kurdish state during the 1919 Paris Conference and Sèvres Treaty's relevant article were not only limited in allowing for the creation of a Kurdish state but also were not implemented. The only area where self-determination was implemented for Kurds, albeit in a very limited and a procedural form, was north Mesopotamia. In this area, the British created a semi-autonomous regional administration called Sulaymaniyah in 1918, in accordance with the ideals of President Wilson's Point 12. lxvii However, this administrative rule came to a quick end when Mahmoud Barzinji, the head of the administrative region, defied the British and rebelled against them.

\section{Conclusion}

Maps and geographic studies typically "reflect and recreate dominant geopolitical discourses" and in the nineteenth century these were linked to orientalist discourses. ${ }^{\text {lxix }}$ In these orientalist discourses, national identity began to be geographically imagined and territorialised, which was the outcome of constructions of national identity and nationalism in the nineteenth century. Spatial categories began to be used to categorise peoples and their ethnic and linguistic characteristics. Such categories started to attain significant explanatory power in studying and mapping nationalism and ethnicity not only in Europe but in other parts of the world as well. Ethnographic maps produced by European travellers and geographers are excellent examples of this kind of thinking. The idea of national territory in the state-centred political geography became an essential and taken-for-granted entity and its presence was seen as a stage (and component) in the social and national advancement and development of a peoplelex to reach to the level of civilisation as experienced in the European context. Such perspectives were ingrained into the nineteenth century and early twentieth century political geography and map-making by colonial geographers and officials.

European travellers' accounts reflect the values and perceptions of the travellers who were representatives of the states that ultimately decided the political future of the region. The orientalist view of the world perceiving non-European peoples as less civilised and underdeveloped informed these accounts. The civilizational understanding of nationalism that considers national consciousness, the degree of shared history, language and culture as an indicator of readiness and criteria for being considered as candidates to join the family of nations constituted the lens through which the European travellers and officers saw the Kurds and other peoples of the region. These European cultural and political values were considered as universal and this perception of universality and superiority informed their views. In addition, their own relatively positive bias towards Christian and other non-Muslim communities also informed their accounts and their view of the Kurds. 
The studies and explorations undertaken in Kurdistan and the reports produced by European travellers and their governments' officials were used to formulate European states' policy with regards to the Kurds before, during and after the First World War. Crucially, the geographical information and anthropological studies about the Kurds constituted the foundation of Kurdish nationalist cartography and historiography in the following decades of the twentieth century. Kurdish nationalists replicated these maps or improvised on them to imagine the Kurdish homeland and its extent. Today the map of greater Kurdistan, extending from the Mediterranean to the Persian Gulf, produced by Kurdish nationalists has become a key symbol of Kurdish national identity and is being used widely by the Kurds. The idea of an independent Kurdistan at some point in the future when the circumstances allow, resonates with many Kurds, both in the region and the diaspora.

Kurds have benefited from significant international and transnational opportunities over the twentieth century and early twenty-first century. For instance, international support for Kurdish self-governance in the form of autonomy within a federal Iraq continues. The US and other western countries have established a strategic and military alliance with Kurds in Syria in the fight against the Islamic State of Iraq and Syria, an alliance that received a fatal blow when the US let a Turkish incursion into the Kurdish controlled northeastern Syria in fall 2019. Kurdish political actors have engaged with contemporary dominant norms, such as democracy, human rights, minority rights and gender equality and self-determination to solicit support for their political legitimacy. However, this does not mean that the international community is ready to support a Kurdish state. Neither the United States, the United Kingdom nor regional countries consider Kurdish secession from Iraq as an acceptable option. ${ }^{\text {.xxi }}$ The lack of international support for the Kurdish independence referendum in October 2017 clearly showed this.

\section{References}

Agnew, John (1994), 'The Territorial Trap: The Geographical Assumptions of International Relations Theory', Review of International Political Economy 1 (1): 53-80.

Alsancakli, Sacha (2017), 'Matrimonial Alliances and the Transmission of Dynastic Power in Kurdistan: The Case of the Diyādinnids of Bidlīs in the Fifteenth to Seventeenth Centuries', Eurasian Studies 15: 22249.

Ateş, Sabri (2013), Ottoman-Iranian Borderlands: Making a Boundary, 1843-1914, New York: Cambridge University Press.

Bajalan, Djene Rhys (2019), 'The First World War, the End of the Ottoman Empire, and Question of Kurdish Statehood: A 'Missed’ Opportunity?’, Ethnopolitics, 18 (1): 13-28.

Bozarslan, H. (2003), 'Kurdish Nationalism in Turkey: From Tacit Contract to Rebellion', in: A. Vali (ed.), Essays on the Origins of Kurdish Nationalism, 163-90, California: Mazda.

Breuilly, John (1993), Nationalism and the State, Manchester: Manchester University Press.

Crampton, Jeremy W. and Krygier, J. (2006), 'An Introduction to Critical Cartography', ACME: An International E-Journal for Critical Geographies, 4 (1): 11-33.

Culcasi, Karen (2006), 'Cartographically Constructing Kurdistan within Geopolitical and Orientalist Discourses', Political Geography, 25 (6): 680-706.

Diamond, Larry and Marc F. Plattner (eds.) (1994), Nationalism, Ethnic Conflict and Democracy, Baltimore: John Hopkins University Press.

Edmonds, C. J. (1971), 'Kurdish Nationalism', Journal of Contemporary History, 6 (1): 87-106. 
UK House of Commons, Foreign Affairs Committee (2018), 'Kurdish Aspirations and the Interests of the UK', Third Report of Session 2017-19.

Freeden, Michael (1998), Ideologies and Political Theory: A Conceptual Approach, Oxford: Clarendon Press.

Harley, J. B. (1989), 'Deconstructing the Map', Cartographica, 26 (2): 1-20.

Harley, J. B. and David Woodward (eds.) (1987), The History of Cartography, Volume 1: Cartography in Prehistoric, Ancient, and Medieval Europe and the Mediterranean, Chicago: University of Chicago Press.

Helmreich, Paul C. (1974), From Paris to Sèrres: The Partition of the Ottoman Empire at the Peace Conference of 1979-1920, Columbus: Ohio State University Press.

House, Edward Mandell and Seymour, Charles (eds.) (1921), What Really Happened at Paris, the Story of the Peace Conference 1918-19 / by American Delegates. London.

Klein, Janet (2007), 'Kurdish Nationalists and Non-Nationalist Kurdists: Rethinking Minority Nationalism and the Dissolution of the Ottoman Empire, 1908-9', Nations and Nationalism, 13 (1): 135153.

Knight, David B. (1985), 'Territory and People or People and Territory? Thoughts on Postcolonial SelfDetermination', International Political Science Review, 6 (2): 248-272.

Kurdish Delegation to the Peace Conference. (1919), Memorandum on the Claims of the Kurd People, Prepared by General Şerif Pasha, Paris.

Laughlin, Jim Mac (1986), 'The Political Geography of 'Nation-Building and Nationalism in Social Sciences: Structural vs. Dialectical Accounts', Political Geography Quarterly, 5 (4): 299-329.

Macmillan, M. (2002), Peacemakers: The Paris Peace Conference of 1919 and its Attempt to End War, London: John Murray.

Maunsell, F. R. (1894), 'Kurdistan', Geographic Journal, 3 (2): 81-92.

Maunsell, F. R. (1890), 'Reconnaissances in Mesopotamia, Kurdistan, North-West Persia, and Luristan from April to October 1888', Vol 2, Simla: Intelligence Branch, Quarter Master General's Dept, [114v] $(233 / 312)$.

McDowall, David (1996), A Modern History of the Kurds. London: I. B. Tauris.

McMurray, Jonathan S. (2001), Distant Ties: Germany, the Ottoman Empire, and the Construction of the Baghdad Railway, Westport: Praeger Publishers.

Meiselas, Susan, (2008), Kurdistan: In the Shadow of History, Second Ed., Chicago: University of Chicago Press.

Mignan, Robert D. (1839), Winter Journey Through Russia, the Caucasian Alps and Georgia: Thence Across Mount Zagros by the Pass of Xenophon and the Ten Thousand Greeks, into Koordistaun, 2 Vols, London: Richard Bentley.

Millingen, Fredrick (1870), Wild Life Among the Koords, London: Hurst and Blackett.

Muhammad, Qadir Muhammad (2017). 'Kurds and Kurdistan in the View of British Travellers in the Nineteenth Century', Doctoral Thesis, University of Leicester. 
O'Shea, Maria. T. (2004), Trapped Between the Map and Reality: Geography and Perceptions of Kurdistan, London: Routledge.

Özoğlu, Hakan (2004), Kurdish Notables and the Ottoman State: Evolving Identities, Competing Loyalties, and Shifting Boundaries, Albany: State University of New York Press.

Rawlinson, H.C. (1839), 'Notes on a March from Zohab, at the Foot of Zagros, along the Mountains of Khuzistan (Susiana), and from Thence Through the Province of Luristan to Kirmanshah, in the Year 1836', Journal of the Royal Geographical Society of London, 9: 26-116.

Rich, Claudius James (1836), Narrative of a Residence in Koordistan, and on the Site of Ancient Nineveh, 2 Vols, Cambridge: Cambridge University Press.

Said, Edward. (1994), Culture and Imperialism, London: Vintage.

Sidaway, James D. (2000), 'Postcolonial Geographies: An Exploratory Essay', Progress in Human Geography, 24 (4): 591-612.

Smith, Anthony D. (2004), The Antiquity of Nations, Oxford: Polity.

Sykes, M. (1904). Dar-ul-Islam, London: Draft Publishers Ltd.

Tilly, Charles (1994), 'States and Nationalism in Europe 1492-1992', Theory and Society, 23 (1): 131-146.

Tyner, Judith A. (1982), 'Persuasive Cartography', Journal of Geography, 82 (4): 140-144.

Van Bruinessen, Martin (1992), Agha, Shaikh and the State: The Social and Political Structures of Kurdistan, New Jersey: Zed.

Wintle, Michael (1999), 'Renaissance Maps and the Construction of the Idea of Europe', Journal of Historical Geography, 25 (2): 137-165.

\footnotetext{
i Said 1994: 6

ii Wintle 1999: 137

iii Ibid. 138

iv Harley 1983

v Tyner 1982; Harley and Woodward 1987: 2

vi Laughlin 1986: 322

vii Although according to Freeden (1998) nationalism is not a full ideology, the way it was used to justify state formations and policies in the nineteenth century could qualify it as an ideology. In other contexts, nationalism can also be a sentiment or a movement.

xv Diamond and Plattner 1994: xii

xvi Tilly 1994; Breuilly 1993

xvii Laughlin 1986: 300

xviii Ibid. 308

xix This section uses O'Shea's excellent analysis of the European engagement with the Kurds and other peoples in the area, and her archival research on European mapping in eastern Ottoman territories in the nineteenth century. xx Sykes, Dar-ul-Islam, p. 202; Maunsell, Reconnaissances in Mesopotamia, Kurdistan, vol. 2, 166. For an excellent analysis of the British travellers' accounts of the Kurds and Kurdistan in the nineteenth century, see Muhammad 2017.

xxi Maunsell, Reconnaissances in Mesopotamia, Kurdistan, p. 166.

xxii Crampton 2001: 235

xxiii Agnew 1994: 67
} 
xxiv Ibid. 67

xxv The third international period Agnew refers to from 1945 to 1990 is outside the focus of this chapter. This period was one in which "interstate competition and conflict were largely transformed by the US reconstruction of the industrial capitalist state along liberal capitalist lines." (Ibid. 67).

xxvi Ibid. 64, 69

xxvii Laughlin 1986: 301; 307-308

xxviii Smith 2004

xxix Agnew 1994: 53-59

xxx Ibid. 60

xxxi Knight 1985: 250-251

xxxii Wintle 1999: 152

xxxiii Ibid. 160

xxxiv Sidaway 2000: 592; Said 1978

xxxv Rawlinson 1839; Rich 1836.

xxxvi Mignan 1839.

xxxvii O'Shea 2004: 109-114

xxxviii The railway connecting Berlin and Istanbul and the role of German military in the reformation of the Ottoman army were important factors.

xxxix $1,266 \mathrm{~km}$ by the end of the nineteenth century.

xl O'Shea 2004: 114

xli Meiselas 2008: 2-50

xlii O'Shea 2004: 108-113

xliii Rawlinson 1839; Alsancakli 2017.

xliv O’Shea 2000: 65

xlv McMurray 2001

xlvi O'Shea 2004: 112-113

xlvii Ibid.

xlviii Ibid. 108

xlix Ibid. 110

${ }^{1}$ Ibid. 48

li For the decades long process of border demarcation, see Ateş 2013.

lii Ibid. 125

liii Ibid. 107

liv Ibid.

lv The Pasha was raised in Istanbul and had Kurdish origins.

lvi House and Seymour 1921: 14

lvii Kurdish Memorandum: 3

lviii Ibid. 12

lix McDowall 1996: 122

1x Özoğlu 2004: 39-40; Bozarslan 2003: 169. Sayyid Abdulkadir, the other leader of the SAK and rival to Emin Ali

Bedirhan, supported Serif Pasha's efforts at the Paris Peace Conference.

1xi Bozarslan 2003: 169; Olson 1991: 399

lxii Van Bruinessen 1992: 279; Bozarslan 2003: 172.

lxiii O’Shea 2004: 129

lxiv O'Shea 2004, pp. 117-118. For the lack of international support for the Kurdish state in the post-World War I period, see Bajalan 2019.

lxv Quoted in Macmillan, 2002: 458, from Lloyd George's diary.

lxvi Helmreich 1974.

lxvii Klein 2007.

lxviii Edmonds 1971: 92. Point 12 in Wilson's Fourteen Poinuts: “The Turkish portion of the present Ottoman Empire should be assured a secure sovereignty, but the other nationalities which are now under Turkish rule should be assured an undoubted security of life and an absolutely unmolested opportunity, security of life and an absolutely unmolested opportunity of autonomous development, and the Dardanelles should be permanently opened as a free passage to the ships and commerce of all nations under international guarantees."

lxix Culcasi 2006: 680

lxx Laughlin 1986: 321

lxxi UK House of Commons, Foreign Affairs Committee 2018. 